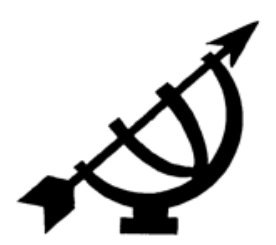

\title{
Communicative action: the Habermasian and Freirean dialogical approach to participatory communication for social change in a post-1994 South Africa
}

\author{
H. Otto \& L.M. Fourie
}

School of Communication Studies

Potchefstroom Campus

North-West University

POTCHEFSTROOM

E-mail: Hannelie.Otto@nwu.ac.za

Lynnette.Fourie@nwu.ac.za

\begin{abstract}
Communicative action: the Habermasian and Freirean dialogical approach to participatory communication for social change in a post-1994 South Africa

Despite its almost four decade mainstay, the field of participatory communication for social change still experiences a definitional and pragmatic problem regarding what exactly participation is (cf. Jacobson \& Storey, 2004; Chambers, 1994; Melkote \& Steeves, 2001; Rogers, 1976; Lerner, 1964; Schramm, 1964; Servaes, 1995). What remains is a vastly under-theorised field of participatory communication for social change. This article examines the possibility of participatory communication approaching the Habermasian "ideal speech situation" in which people, as communicators, are seen as having a value in their own right and not simply regarded as a means to an end (cf. Habermas, 1984; 1987; 1989). Consistent with the Freirean "liberal pedagogy", the praxis of dialogical communication or intersubjective communication is seen as putting right the "participative" quality of participatory communication (cf. Freire, 1970). For both theorists, transformative action can only occur if reflective and collective learning occurs in linguistically constructed settings where the normative dimensions of truth (logos), rightfulness (ethos) and truthfulness (pathos) are raised and met in the developmental conversation. This is especially significant in a globalised world and frag-
\end{abstract}


mented, post-bourgeois public sphere where debate among developmental stakeholders is becoming more marginal, instrumentalist, and less public. Based on available analyses of development communication literature, this article proposes that the chosen dialogical approaches share a type of communicative behaviour (i.e. action theoretic), rather than representing a particular paradigm or school of thought. This could offer further definitional clarification of proper participatory communication for social change in a post-1994 South Africa.

\section{Opsomming}

\section{Kommunikatiewe aksie: die dialogiese benadering tot deelnemende kommunikasie vir sosiale verandering volgens Habermas en Freire}

$\mathrm{Na}$ bykans vier dekades is daar nog steeds nie eenstemmigheid in die deelnemende kommunikasieveld vir sosiale verandering oor presies wat deelname behels of hoe dit prakties toegepas behoort te word nie (cf. Jacobson \& Storey, 2004; Chambers, 1994; Melkote \& Steeves, 2001; Rogers, 1976; Lerner, 1964; Schramm, 1964 Servaes, 1995). Die gevolg is dat daar nog baie min geteoretiseer is binne die veld van deelnemende kommunikasie vir sosiale verandering. Hierdie artikel ondersoek die moontlikheid dat deelnemende kommunikasie in die vorm van Habermas se "ideale spraaksituasie" as uitgangspunte vir die definiëring van deelname gebruik kan word. In hierdie "ideale spraaksituasie" word persone as kommunikeerders waardevol geag en nie slegs as objekte beskou nie (cf. Habermas, 1984; 1987; 1989). Ooreenstemmend met Freire se liberale pedagogie van ontwikkelingskommunikasie, word die praktyk van dialogiese kommunikasie of intersubjektiewe kommunikasie as die regstelling van die deelnemende karakter van deelnemende kommunikasie geag (cf. Freire, 1970). Vir albei teoretici kan transformatiewe aksie slegs in reflektiewe en kollektiewe linguistiese kontekste plaasvind. Hier moet die normatiewe dimensies van waarheid (logos), geregtigheid (ethos) en opregtheid/empatie (pathos) tydens die ontwikkelingsdiskoers gestel, getoets en eindelik aanvaar word. Veral in 'n geglobaliseerde wêreld en in 'n gefragmenteerde, post-bourgeoisie publieke sfeer waar debat tussen ontwikkelingsrolspelers toenemend gemarginaliseerd en instrumenteel word, asook progressief minder toeganklik en deelnemend vir die samelewing is, is geleenthede vir toeganklike en onbelemmerde debat des te meer nodig. Gebaseer op die beskikbare analises van die ontwikkelingskommunikasieliteratuur, stel hierdie artikel voor dat die gekose dialogiese benaderings dieselfde kommunikasiegedrag veronderstel - dit wil sê wat aksie-teoreties van aard is eerder as wat dit 'n 
spesifieke paradigma of denkskool verteenwoordig. Hiervolgens kan die definisie van deelnemende ontwikkelingskommunikasie vir doeltreffende sosiale verandering in 'n post-1994 Suid Afrika verfyn word.

\section{Introduction and orientation}

The end of apartheid in South Africa in 1994 resulted from remarkably consultative and inclusive social and political developments previously not witnessed in the country's political history of colonial power and racism. After its much-celebrated negotiated transition, South Africa adheres to the dominant definition of liberal democracy offered by Huntington (1991:7), who conceives a political system as being democratic:

... to the extent that its most powerful collective decision makers are selected through fair, honest and periodic elections in which candidates freely compete for votes and in which virtually all the adult population is eligible to vote.

Legitimacy is, however, not only conferred by democratic electoral practices, but also through the forming of common opinions and critical voices against those elected by citizens as their representatives, making a purely liberal democratic description of South Africa reductive. Despite the repeal of key apartheid legislation and recent positive economic growth, the legacies of apartheid remain evident in the daily socio-economic realities ${ }^{1}$ of most South Africans (Hart, 2006:27; Hoogeveen \& Özler, 2006:59-60).

Liberation and democracy discourse in South Africa necessitates an account of not only social and political transformation processes, but also of economic transformation 2 (Duvenhage, 2007:378; Neocosmos, 2002:6). The period after 1994 saw South Africa accordingly intensely engaged in economic modelisation and remodelisation

1 Overall, the living conditions of the vast majority of South Africans remain poor. In this country the average life expectancy is 44 years, and the official unemployment rate $23 \%$; HIV prevalence is $18,8 \%$ for persons aged between 18 and 49; there are rising income inequality and violent crime; also, basic infrastructure is lacking and service delivery is poor. All these aspects continue to counteract many of the success stories of the democratic consolidation process in South Africa (World Bank, 2006:289).

2 During the period of 1983 to 1994, South Africa's per capita income fell about $15 \%$, causing an economic crisis to speed up in the years preceding the political transition (Hirsch, 2006:xiii). 
(Chambers, 1994; Hart, 2006:13-14; Melkote \& Steeves, 2001; Padayachee, 2006:1-3). Since the democratic transition period, the construction of sound democratic foundations also entailed the reconstruction of the economy and the expansion of socio-economic rights through redistributive macro-socio-economic steering 3 (Hirsch, 2006:xiii). Parsons (2001:141-142) advises, however, that in order for a postapartheid society to work toward such a common task as economic participation, trust must be reinstituted as a concept in what he terms social dialogue. Using the terms social dialogue and social capital interchangeably, he poses the argument that an economically "efficient" society built on networks of trust and reciprocal "give-and-take", "compromise" and "consensus-seeking" is needed in a post-1994 reality. In his words:

... a low trust society imposes a type of tax on all forms of economic activity, apart from its potential threat to social stability in a 'worst case' scenario. (Parsons, 2001:142).

This marks a shift away from paternalistic thinking, where state-led developmentalism is non-dialectical, precluding or weakening institutions of intersubjective economic policy-making (Friedman, 2004:186; Romm, 1990a:34-35, 37; Alant, 1990a:61-62). While dialogue on the economic restructuring of South Africa is vital, political, cultural, and social dimensions should also be taken into account. Parsons (2001:169) accounts for this when saying that the:

... social dialogue process and structures in South Africa have not escaped the stresses and strains of the new democracy they were designed to help consolidate.

Explaining the continuing revision of the economic framework, Duvenhage (2007:378) describes it not as a purely economic logic, but one that fits within the ANC-government's political ideology of radical transformation of the state, society and the economy.

From this perspective, a National Democratic Revolution is envisioned that would

3 For more comprehensive analyses on South Africa's economic reform and development discourse, refer to:

Padayachee. V. 2006. The development decade? Economic and social change in South Africa, 1994-2004. Cape Town: HSRC.

Bhorat, H. \& Kanbur, R. 2006. Poverty and policy in post-apartheid South Africa. Cape Town: HSRC. 
... identify the variety of methods at the disposal of revolutionaries to achieve a united, democratic, non-racial, nonsexist and prosperous society (ANC, 2002).

The ANC-led government characterises this revolution as playing out at the intersection between "national oppression and capitalistic exploitation" so as to improve the quality of life of the poor majority of citizens. Reviewing the continuing legitimacy of our democracy (i.e. its accountability and its responsiveness to "its people's" needs), proper reflection and valid action on how development and democracy dovetail are needed if the severity and depth of unequal economic opportunity in South Africa are to lessen (Kajee, 2006: 242; Mail and guardian, 2006; 2007). Such thought echoes in President Jacob Zuma's words when he said that at "the heart of our democracy [is the idea] that the people shall govern" by actively participating in the daily running of government (Zuma, 2009).

In postapartheid development discourse, academics from a myriad of disciplines, as well as practitioners and policy formulators in diverse public and private spheres thus continue to specify and contest the nature of "development" and its ends, besides determining the best institutional frameworks and strategies by which to achieve this (Hart, 2006:14; Storey, 1999:337-339; Van der Walt, 2007:469-470; Waisbord, 2001; Rogers, 1976; Servaes, 1995).

\section{Conceptual and theoretical departure points}

\subsection{Democracy and development: a new "state" of participation?}

From a normative observation, growth strategies alone cannot lift the vast numbers of South Africans out of their deprived circumstances. Economic strategy cannot exist in a socio-political vacuum.

A critical element of the National Democratic Revolution emphasises the

... pooling of the power of state capital and institutional and social capital in the hands of the motive forces; encouragement of the co-operative sector; as well as systematic and intelligent ways of working in partnership with private capital in a relationship that will be defined by both unity and struggle, cooperative engagement and contestation on fundamental issues. It requires the elimination of the legacy of apartheid superexploitation and inequality, and the redistribution of wealth and 
income to benefit society as a whole, especially the poor. (ANC, 2002.)

Duvenhage (2007:382, 399-401) warns that this ideological philosophy implies serious drawbacks as well as positive, although perhaps determinate, outcomes for sustainable development in South Africa. He analogises a political ideology (i.e. political transformation) to Lakatos's theory about scientific research programmes' development (Duvenhage, 2007:381; cf. Lakatos, 1970:132-138). According to Lakatos (1970:132) particular scientific research programmes have a so-called "negative heuristic" or "hard core". Additionally, they have a "positive heuristic" or a "protective belt" that surrounds the hard centre. The hard centre then constitutes the programme's fundamental or philosophical convictions and the "softer periphery" of theory or conceptual frameworks functions as the core's so-called protective belt (Duvenhage, 2007:381; cf. Lakatos, 1970:132). It follows, Lakatos explains, that the substance (i.e. the fundamental philosophy) of the ideology could gain constancy, as the "protective belt" (i.e. the socio-political program) not only safeguards its content, but also ensures the expansion thereof. This is especially true when the socio-political programme fails to enact the intended ideological vision (cf. Duvenhage, 2007:382, 385-386).

At the centre of the ruling party's transformation ideology is the concept of a "developmental state". Its understanding of such a state is that the latter stands at the centre of a "mixed economy" or twotiered economy (Mantashe, 2008:24). Through state-led intervention and guidance, it supposes that the commonwealth of citizens are tended to as liberal democracy and globalised economic conditions fail to address economic justice and equal opportunity. Consequently, some contend that democracy and development are not only compatible, but also mutually reinforcing; hence, the African call for the so-called democratic developmental state.

In its most rudimentary form, the democratic developmental state is defined in corporatist terms where the state intervenes more directly in the economy through institutional structures and objectives in the distribution of wealth instead of allowing only the market to determine the distribution thereof (Edigheji, 2008:6; Robinson \& White, $1998: 2,5-6,11)$. The process of development that the ANC-led government envisions is, however, also clearly situated in an envi- 
ronment of "people centeredness" or popular democracy. 4 In keeping with such thought, a democratic state should not loose sight of the fact that the people "make" the democracy.

Recent uprisings and protests across South Africa on poor municipal service delivery certainly appeal to conceptions of grass roots democracy or the use of "people's power" where the nature of democracy, and its offshoots, are collectively decided and debated among a myriad of stakeholders in the public sphere. Neocosmos (2002:8) explains that this type of participatory and public debate is especially crucial in a country where the modes of rule have not yet been sufficiently debated since the initial discussions that took place during the 1980s in the ambit of the United Democratic Front.

Some commentators argue that the South African practice of "democratic centralism" and vigorous debating from across the political spectrum, regarding capitalism versus socialism seem more preoccupied with economic relations than with political ones in which not only the formal conventions of democracy are examined, but also those informal practices that have bearing on the democratic process (Neocosmos, 2002:7; Vavi, 2008). Friedman (2004:186), reviewing the obvious and concealed costs of enforcing the 1994 GEAR (Growth, Employment and Redistribution) macro-economic strategy, counsels that the "discouragement of difference impairs prospects for growth" and the legitimacy of government in general. $\mathrm{He}$ also warns against purely instrumentalist and economic reason in the development policy framework of government when saying that "... [b]y setting an over-ambitious government goal ... unnecessary political opposition to government's current macroeconomic strategy" is created (Friedman, 2004:186). As globalisation is eroding the decision-making power of nation states, their autonomy is also compromised when broad based debate is suppressed; consequently their ability to articulate and achieve policy goals inde-

The ANC defines itself as social democratic and hence as the guardian and liberator of a democratic non-sexist and non-racial South Africa where "the people shall govern". Various policy and historical documents have underpinned this basic creed of the governing party, starting with the party's 1955 Freedom Charter and the 1994 Reconstruction and Development Programme. Such policies also include macro-economic frameworks such as the Growth, Employment and Redistribution (GEAR) plan (1996), as an orthodox neo-liberal strategy, and the Accelerated and Shared Growth-South Africa, as a national shared growth initiative (ASGISA) in 2006 (ANC, 1955; Cassim, 2006:56-57; South Africa, 2006; 1996; 1994). The concern of deepening participatory democracy thus permeates the fundamental character of the ANC. 
pendently of wider collective debate weakens (Eriksen \& Weigård, 2003:249).

Commentators and detractors of the democratic developmental state caution that the ANC is merely using such rhetoric at a time that their ideological vision of a development agenda often disappoints at the practical levels of implementation and impact. In the absence of clarity of the meaning of development and democracy, and the means by which to reach it, disappointment and failure to meet government-led development goals, therefore seem likely (Meth, 2006:434).

With the aim of testing the legitimacy of the fledging South African democracy, socio-economic inequalities must be investigated and redressed, but not simply by state-led and market-led practices, but also by practices of debate and discussion between the former and civil society. What is critical in this process is the capacity of social and popular movements, the private sector, and the public sector to forge partnerships with one another on development discourse and practice.

From a normative communicative standpoint, participative strategy planning seems to be at the centre of such practice and here the dialogical approaches to social change of Paulo Freire and Jürgen Habermas could shed light on such thinking (cf. Freire, 1970; Habermas, 1984; 1987). Edigheji (2008:3) explains that it is here that representative and participative democracy intersect - i.e. citizen participation in the development and governance processes is crucial. He further explains that for this participation to occur, open and public "cooperative work" and "deliberative traditions" of consultative decisions making networks should complement electoral practices. As Duvenage (2005:1) and others (Eriksen \& Weigård, 2003:111, 202) explain, in communication studies the concept of the public sphere and its relationship to a functioning democracy is a major concern. The authors inquire about the nature of the concept public and its relation to its opposites such as the domestic private sphere, the sphere of secrets and indeed the economic private sphere.

Rephrasing this concern, this article asks whether the normative Habermasian bourgeois public sphere or ideal speech situation could be reconstructed in order to balance South Africa's economic development measures with public social values aimed at the common good. In other words, could a public sphere based on Freirean preconditions of participatory deliberation function as a setting or an 
ideal speech situation where participation and debate or communicative action $\mathbf{5}$ on socio-economic development occur?

\section{Communication for social change}

\subsection{From fixed definition to deficient description}

Before turning our attention to the Freirean dialogical praxis and the Habermasian communicative action theory, a succinct review of the place of theory in development communication of recent years follows (cf. White, 1994; Wilkens, 2002). What underpins our basic observations is that more rigorous conceptual exploration and theoretic rationale for communication planning about development should take place. Concurrently, such theorisations should not loose sight of the concrete and different contextual settings in which they are supposed to apply (Roman, 2005:311-312).

Development communication theory and practice are replete with interdisciplinary philosophies, concepts, definitions, approaches and models of how one should theorise and properly organise for social change (and by implication democratisation and democratic consolidation). In such a theoretically diffuse study field, more rigourous theory building is necessary. From our assessments, clear signs of epistemological and methodological fissure from the modernisation theory's 6 orthodox economic growth conceptualisation and topdown, linear communication methodology are evident. A fixed description of development communication is nonetheless absent. More precisely, the lack of theoretical coherence is apparent as much as normative theory of participatory communication for social change 7 intends to replace simplistic, descriptive analyses. For the purposes of this article, development communication is described as "attention to the communication about development, or its discourse" (Wilkins, 2002:537).

Although we accept that the concepts of social dialogue, tripartism, civil society and even corporatism could be substantiated and understood in a variety of ways and traditions, this article interchanges it with the notion of communicative action.

Although the dominant paradigm has lost its theoretical station, it has not completely abandoned its authority in political or institutional settings (White, 1994:16-17).

It was as early as the seventies that Rogers and Shoemaker (cf. Rogers \& Shoemaker, 1971:76-85) called for a wider role and place of communication in development (Nair \& White, 1993:48). 
This article consequently does not concern itself primarily with the methodological practice of communication for development (i.e. on practice or project level), but rather with analyses of the development discourse. That is to say, this article is concerned with understanding institutional settings, practices and conditions necessary when examining the meaning of development problems and how this could be addressed through strategic interventions (including communication for development). When placing a premium on cooperative and deliberative networks, it is therefore necessary to understand how institutionalised dialogue should or could be normed according to established participatory communicational paradigms (Alant, 1990b:10; Romm, 1990b:21).

Jacobson and Servaes (1999:2) define participatory development communication as a dialogic process, while Melkote and Steeves $(2001: 34,37)$ view it as social relations aimed at empowering individuals via a collective empowerment mode. Amid the various interpretations of power and its effects, the collective empowerment model is concerned with the exercise of power on organisations, people and their practices, so that communities can take control of their personal, actual development circumstances (i.e. socio-economic realities) (Zaaiman, 2007:373-374). Development, or the lack thereof, is not merely described as the "communication of information" (i.e. the classical transmission model) for improving societal living conditions, but as a definitional varied concept, that requires miscellaneous understandings, strategies and methods.

\subsection{The Freirean dialectical dialogue praxis for communication for social change}

Following the normative prescription of participatory communication, discourse among strategic partners in a public sphere should examine directed social change from the perspective of accommodating concepts such as conscientisation, communicative action, dialectic control and influence, acknowledging the weaknesses of earlier positivistic thought (Chitnis, 2005:229, 234). As Romm (1990c:115, 123) explains, government representatives, employers and workers, social movements and citizens alike should become willfully selfaware of how they can exchange information on how to best achieve decided development objectives. Romm quotes Berger (Romm, 1990c:123) in saying that for humane and proper development policies to manifest, all affected social actors must participate cognitively in policy-making. 
The Brazilian educator Paulo Freire, combining influences from North and South, is perhaps best known for incorporating an empowerment and participatory action framework in development communication discourse and practice. In his pioneering work of the 1970s, that is liberation theory of development, Freire emphasises that in development discourse actors are not cast according to a subject-object dualism, but in a subject-object duality where every participant learns collectively via dialogue and interchangeable roles, using it as methodologies of empowerment and social change (Barranquero, 2006:921; Närman, 2006:98-99). If one accepts that democracy is more than just an electoral standard, Freirean thinking sets the scene for communicative action or social dialogue in a liberal democratic setting such as South Africa where apartheid's socio-economic fissures still feature prominently.

Freire's critique of the traditional "banking model" or monological mode of education describes actors as knowledgeable, conscious beings capable of negotiating the limits of their worlds and the oppressions experienced in it (Chitnis, 2005:236; Morrow \& Torres, 2002:1-2). As Alant (1990a:65) proposes contrasting action types can be dialectically combined, keying in on the process of ethical and more humane communication rather than purely the message of the communication as a predetermined condition. Servaes (1995:46) famously recaps this position. In organising for social change, development agents and partners do not merely talk to the intended audiences, but rather talk with the participants in an effort to determine what type of information is needed.

Freire's dialogical approach, inspired by practical experiences of oppression, could thus overcome the typical Western thinking of development in so far as it accommodates and determines the varied ontological reasons for communication - in this case to effect positive social change (Barranquero, 2006:920). In describing a reflexive sociological approach and its application in the South African society, Romm (1990b:14, 18) argues that this type of adjusted communicative discourse and behaviour are similar to a social learning experience. In this view knowledge is co-created and inseparable from the willingness and ability of all actors to accommodate "bad news" in their own conception of truth in a meaningful manner.

This action type fits with South African policy, which values lifelong learning not only in pedagogical settings, but also on an organisational delivery level in various governmental institutions and bureaucracies. A communicative or intersubjective paradigm of this sort could thus broaden not only development discourse but also 
action to this effect. This contrasts positivistic and top-down, macrosociological development discourse and praxis. In the communicative paradigm, however, communicatively enabled South Africans regain their agency in socio-economic policy-making by "demystifying" for themselves their realities and the implicit relationships of oppressions therein. As Barranquero (2006:921) states, societal planning becomes dialogical, emancipatory and pro-democratic communication. In Freirean ontological terms, this is the process of conscientisation or discursive consciousness. This action-reflection (praxis) enacts empowerment because of the changed relationship between teacher (knowledgeable agent or policy maker) and learner (ignorant agent or citizen) that creates a problem-posing realism (Chitnis, 2005:240; Morrow \& Torres, 2002:34). By using language actors are able to develop a critical consciousness regarding their life opportunities and the relations of power and oppression that are inhibiting positive social change (Morrow \& Torres, 2002:36-38).

In a postapartheid society, Freire's transformative praxis of dialogue intends to reinstate the bonds of trust and "humanness" that was missing in the positivistic theory of reality as it operates in a humanist and existentialist ontological framework (Alant, 1990b:4). This framework avoids the typical essentialist conception of the human subject, since the act of knowing is an act of intercommunication or intersubjectivity between subjects and not simply a monological act of rationality. For the South African context, this type of dialogical praxis could be a particularly relevant shift away from the traditional paternalistic development discourse and practices to more inclusive and consensual decision-making frameworks. This is especially relevant in the context of a democratic developmental state ideology. Freire's dialogic theory could thus facilitate a broader understanding (i.e. multiplicity of ideas) of what a South African developmental state could look like in its nature and form inasmuch as development is not only economic growth, but also includes more inclusive forms of participation and practice in development discourse and strategy (Robinson \& White, 1998:11).

\subsection{The problem of power in discursive relationships}

The conditions and rules under which dialogical praxis on developmental discourse occurs could, however, be both enabling and constraining. The dialectic of control and power between actors engaged in interaction remain problematical in development discourse, including Freirean praxis. 
Jacobson and Storey (2004:100) caution that Freire, in a Marxist manner, overemphasises the subjection of the oppressed rather than appreciating the flowing nature of power in society and thus, to some extent, its availability to agents. It is, however, not sufficient to appreciate the knowledgeability of agents, but also essential to value that participatory communication occur in existing power relations. The epistemological assumption is that dialogue happens between the elites and the oppressed, creating the added task of examining participatory communication within the organisational structures of such power relations and their larger social settings. Often, in the company of power dynamics, social dialogue results in concession for further agreement and discussion instead of only policyformulation with agreed upon objectives and specific mandates.

The communicative action theory of Habermas could, however, provide a framework by which to challenge the continued reproduction of discursively created knowledge on development discourse that reinforces existing structures of domination and oppression. The procedural nature of the public sphere and practice of communicative action are investigated to determine its value for dialogue under oppressive circumstances. Where Freire criticised modernist thinking, Habermas attempts to continue the modernist project by elaborating "rationality" as communicative rationality. Habermas also offers new avenues of thinking about not only how society is reproduced, but also changed and modified by way of discursive communication among diverse participants.

\subsection{Communicative action in a revised public sphere}

The central idea of Habermas's classical model of the bourgeois public sphere (Öffentlichkeit) is that it serves as a collective or community of individuals who jointly partake in rational-critical debate on issues of a general interest (Habermas, 1989:14-26). This historical category of the normative public sphere responded to Horkheimer and Adorno's dialectics of enlightenment. Habermas counters their over-pessimistic interpretation of the rational, progressive aspects of modern society by focusing on those instances where rationality assumes communicative action or a proper function of understanding "the social world and to guide social change by illuminating potentials for social change" (Finlayson, 2005:9).

His epistemology can be termed as critical social theory that is quite different from either classical Marxism or positivism (Morrow \& Torres, 2002:2). 
Habermas's ontology includes a dualism between subject-object relations (i.e. instrumental actions) and subject-subject relations (i.e. communicative actions). In this dualistic relationship, rationality is understood as either being instrumental in nature (i.e. strategic mastery of reality) or on the other hand communicative where mutual understanding is the basic telos (Goode, 2005:25; Habermas, 1984:11; Rasmussen, 1990:5; Strauss, 2006:103, 115). Communicative action is therefore under constant threat of strategic action. To expose and correct this threat, strategic actions or systematically distorted communication that negate mutual understanding and dialogue should be uncovered (Habermas, 1984:332-333). One of the central tasks of democracy would be to determine public opinion in association with political action. Habermas would have it that an ideal speech situation is the sphere in which political participation could take place in the form of language and debate (Alfaro, 2006:908, 909).

His claim is that communicative action presumes language as the means for reaching some kind of understanding (i.e. a pragmatic interest), where in a situation of discourse ethics, communicative participants use language to create meaning, co-ordinate actions and create social order (Habermas, 1984:99). In a more fixed sense, evident in Habermas's more recent work, pragmatic discourse between individuals is considered the dialogical use of instrumental reason on means to reach the given, though not the choice of, ends (Finlayson, 2005:91-92). Within South African institutional practice of social partnerships in public sphere settings, such discourse ethics could find a particular relevance. More precisely, discourse ethics could norm organisational communications and intended actions for more unitary purposes - i.e. discussing improved socio-economic policy and strategic planning.

In viewing participatory communication from the Habermasian angle, communicative action is a procedural and facilitative methodology of interaction and knowledge-construction.

\subsection{Communicative action as social dialogue in post-1994 South Africa}

Relying on interdisciplinary insights, the public sphere has particular relevance for communication studies, and by extension the spheres in which communicative actions take place. In South Africa, the public sphere conception could suffice as a means of immanent critique of existing development discourse and practice. Of particular importance is the participation of the organs of civil society in such 
structures, as the former is often seen as the conscience of society (i.e. the oppressed). If and when agents seek to explore specific socio-economic ends, as in the case of South Africa's goal of economic growth and redistribution, communicative action could be employed to structure discourse with specific ends in mind. More empirical evaluations of the role of social dialogue in South African socio-economic policy-making and its influence on society are however necessary. It must be acknowledged as well that the alternative of ill-informed and disjointed development discourse practices of the past be set aside.

In discovering the truth about socio-economic realities, Habermas proposes a theory of truth based in the use of validity claims. Morrow and Torres (2002:41-42) explain that the key assertion of this theory is that people can coordinate their activity through reciprocal and implicit appeals (i.e. the ideal speech situation) to truth or fairness, sincerity or truthfulness, and rightness where:

- truth refers to the actual experiences or empirical propositions about the world that communicative partners believe to be true;

- sincerity refers to the act of communicative partners sharing true intentions that give mutual trust needed for open and honest communication; and

- rightness refers to the socially accepted rules or mutually recognised normative principles in operation when actors communicate (cf. Habermas, 1984:99, 302-309).

Eriksen and Weigård (2003:46) summarise that this communicative rationality "not only answers questions about facts, but also socalled practical questions about further action, i.e. ethical, legal and moral dilemmas."

This does not discard the fact that the use of rationality is infallible, but rather that it could be viewed in a procedural sense and not only a monological one. 8 Knowledge is a claim or proposition about reality that has been tested and retested through dialogue or the socalled force of the better argument in an action-coordinated setting among agents (Habermas, 1984:10, 18). Once more, this does not reject the claim that deceptive or distorted communication cannot

8 This line of thinking is echoed in Alant (1990a; 1990b), which examines among other "existential" humanism as paradigm for reflecting on development in South Africa. 
and will not take place. Rather, it raises the concern about power politics and the willingness of dialogue partners to partake in discourse under the conditions of the ideal speech situation.

This concern with power politics has particular relevance in postapartheid South Africa. Where the historical tendency was one in which development discourse was located in separatist, racial and cultural specific terms, communicative action could explore the different cultural contexts and lifeworlds (lebenswelt) present in our society; consequently it can also explore the different meanings and contexts of postapartheid social change. Alternatively, as Jacobson (2003:29-30) puts it, development reflection embodied in communicative action provides the possibility of uncovering new behavioural options in the wake of desired and unfavourable social and cultural change. Properly structured, communicative action could be beneficial to more integrated development discourse and practice.

\section{Participatory communication: Freirean praxis as communicative action}

From the discussions above, it is evident that both in Habermasian and Freirean terms, participatory communication is action-oriented behaviour towards understanding. Based on the concepts of individual agency, emancipation, and a dialogical construction of knowledge, both theorists argue for the discursive negotiation of development discourse under conditions of optimal socialisation. Both theorists move development discourse beyond traditional materialist and modernist thought by identifying dialogical communication as the precondition of social change.

This dialogical view does not discard the fact that normative reason cannot be constructed instrumentally, but rather that it must be dialogically constructed if continued relations of dominance and oppression are to be corrected (Morrow \& Torres, 2002:52-53). Those criticising communicative action as utopian and idealist are often not cognisant of the fact that rationality can be interpreted in a more positive sense - i.e. communicative rationality that seeks to uncover factors inhibiting understanding and action-coordination. Habermas and Freire presume new models and categories of communication for a subject that can understand and know the world in intersubjective terms - i.e. in a dualistic social paradigm. Goode (2005:3) explains that critics who choose the historical, unrevised account as Habermas's only concern, risk dismissing the alterative interpretation of the public sphere from a more positive 
dialectical viewpoint or ideological critique. A positive historical dialectic indicates a public sphere where rationality and irrationality are not binary opposites. It rather points towards a merging of a single, historically distinct public sphere, but within a plural, diverse modern-day category of contemporary politics.

From both Habermas's and Freire's standpoints, participatory communication is understood as a non-linear process and an act of creating meaning collectively. As an empowerment exercise, Freire's subject can emancipate itself from oppressive relations and circumstances through reciprocal praxis, while Habermas's subject can continue on this empowerment path by testing democratic legitimacy through discursive power or communicative action (Chitnis, 2005:248).

Far from having the space to treat all criticisms aimed at Freire and Habermas, this article intended to discover how, although largely conceptual in nature, dialogical praxis and communicative action offer principles that could and should be empirically tested. In this manner, the processes of participatory communication for meaningful social change can be better theorised.

\section{Conclusion}

In 2009 the ANC-led government went to the polls focusing not only on economic growth, but also on the quality and expansion thereof for "a better life for all". The ruling party has frequently maintained that economic reformation in postapartheid South Africa requires "an effective, democratic and developmental state", able to take charge in the identification and defining of national priorities, mobilising social and private partners in concretising such priorities, and organising the necessary resources required for reaching such objectives (Mantashe, 2008:24). While enticing, given the country's socioeconomic realities, the democratic developmental state still lacks proper substance and particular structure. Improved and continued public debate and discussion, that is development discourse, might open up room for the government to behave developmentally appropriate (i.e. developing proper state capacity for good governance), but also for citizens to act in a civic-minded and participative way (Ramphele, 2008:18, 142, 146).

Although no signal formulation of development communication exists, development discourse can no longer follow the positivistic tradition of instrumentalist and top-down reason (cf. Freire, 1970; Habermas, 1984; 1987). The normative participatory methodology of 
communication puts the humanness or intersubjectivity of development back on the agenda. Even if this practical paradigm remains epistemologically and methodologically indistinct and undertheorised, there are clear signs in recent literature of theory building. Chitnis (2005:323) agrees that the normativity of the participatory approach should be understood as an interdisciplinary and "flexible guide for action" that can be defined and refined through "action and reflection". Normative theory may be assessed by some, and often with good reason, as idealistic and prescriptive, but in this article it is argued that the usefulness of communicative action and dialogical praxis should be tested in public fora.

This article shows that Habermas and Freire share commonalities in their social theories particularly on understanding action or agency as intersubjective communicative relations of mutual recognition (Barranquero, 2006:922-923; Jacobson \& Storey, 2004:107; Morrow \& Torres, 2002:3). Similarly, both theorists argue for a conception of democracy that occurs within the context of capitalism and power struggles. Both reconceptualised praxis, although Freire from a radicalisation of his dialogical praxis, and Habermas from a revision of historical materialism founded on communicative action theory, as a collective learning experience. Individual agency and the act of knowing is therefore not a monological experience, but rather a permanent and transformative dialogical praxis.

The domain of development communication could benefit from both theorists' understandings of individual agency in relation to development in contemporary capitalistic societies. What remains to be seen, however, is how such theory can develop into useful empirical measures of communicative action for development in South Africa. Certainly, this is an area to be explored in future research. Such efforts could identify and explore those institutional settings where government, capital and labour meet with the intention to discuss how the socio-economic challenges of South Africa could be managed. Such a research intention should seek out those specific fora or social networks where institutionalised tri-partism is at the order of the day. In such public sphere settings, the preconditions and principles of Habermasian and Freirean communicative praxis should be raised and their usefulness empirically tested. To be sure, the consultative processes should be tested for their own value, but also for their intended integrated actions and outcomes.

Supporting the notion of South Africans becoming their own agents of development, we close with the following thoughts from business leader, activist and academic Mamphela Ramphele (2008:26): 
[T]ackling dilemmas successfully requires the willingness to abandon the tendency of dealing with issues on an either-or basis.

and

[A] holistic approach that exploits links between clusters of problems and their solutions allows one to harness synergies by marrying apparently contradictory policy frames.

\section{List of references}

ALANT, C. 1990a. Society as dialogue. (In Alant, C., ed. Sociology and society: A humanist profile. Johannesburg: Southern Book. p. 51-71.)

ALANT, C. 1990b. On dialogue sociology: an exploration. (In Alant, C., ed. Sociology and society: a humanist profile. Johannesburg: Southern Book. p. 7-12.)

ALFARO, R. 2006. Excerpt from: state and civil society: a collaborative or cautionary relationship? (In Gumucio-Dagron, A \& Tufte, T., eds. Communication for social change: anthology, historical and contemporary readings. South Orange: Communication for Social Change Consortium. p. 905-911.)

ANC. 1955. The freedom charter. http://www.anc.org.za/ancdocs/history/ charter.html. Date of access: 12 Nov. 2008.

ANC. 2002. People's power in action preface to the strategy and tactics of the ANC. http://www.anc.org.za/ancdocs/history/conf/conference51/strategy html Date of access: 12 Nov. 2008.

BARRANQUERO, A. 2006. From Freire and Habermas to multiplicity: widening the theoretical borders of participative communication for social change. (In Gumucio-Dagron, A \& Tufte, T., eds. Communication for social change: anthology, historical and contemporary readings. South Orange: Communication for Social Change Consortium. p. 920-924.)

CASSIM, R. 2006. Reflections on South Africa's first wave of economic reforms. (In Padayachee, V., ed. The development decade? Economic and social change in South Africa, 1994-2004. Cape Town: HSRC. p. 55-85.)

CHAMBERS, S. 1994. Participatory rural appraisal (PRA): analysis of experience. World development, 22:1253-1268.

CHITNIS, K. 2005. The duality of development: recasting participatory communication for development using structuration theory. Investigación y

Desarrollo, 13(2):228-249.

DUVENAGE, P. 2005. Habermas, the public sphere and beyond. Communicatio, 31(1):1-12.

DUVENHAGE, A. 2007. Politieke transformasie as 'n ideologiese denkraamwerk: 'n beleidsdinamiese analise en perspektief. Koers, 72(3):377403.

EDIGHEJI, O. 2008. Introduction: public sector reforms and the quest for democratic developmentalism. Africa development, 33(4):1-13.

ERIKSEN, E.O. \& WEIGÅRD, J. 2003. Understanding Habermas: communicative action and deliberative democracy. London: Continuum. 
FINLAYSON, J.D. 2005. Habermas: a very short introduction. Oxford: Oxford University Press.

FREIRE, P. 1970. Pedagogy of the oppressed. New York: Herder \& Herder.

FRIEDMAN, S. 2004. An act of will: manual and the politics of growth. (In Parsons, R., ed. Manuel, markets and money: essays in appraisal. Cape Town: Double Storey. p. 173-196.)

GOODE, L. 2005. Jürgen Habermas: democracy and the public sphere. London: Pluto.

HABERMAS, J. 1984. The theory of communication action: reason and the rationalization of society. Transl. by $\mathrm{T}$. McCarthy. Boston: Beacon.

HABERMAS, J. 1987. The theory of communication action: lifeworld and system. Transl. by T. McCarthy. Boston: Beacon.

HABERMAS, J. 1989. The structural transformation of the public sphere: an inquiry into a category of bourgeois society. Transl. by T. Burger \& F. Lawrence. Cambridge: Polity.

HART, G. 2006. Post-apartheid development in historical and comparative perspective. (In Padayachee, V., ed. The development decade? Economic and social change in South Africa, 1994-2004. Cape Town: HSRC. p. 1333.)

HIRSCH, A. 2006. Foreword. (In Bhorat, H. \& Kanbur, R., eds. Poverty and policy in post-apartheid South Africa. Cape Town: HSRC. p. xiii.)

HOOGEVEEN, J.G. \& ÖZLER, B. 2006. Poverty and inequality in postapartheid South Africa, 1995-2000. (In Bhorat, H. \& Kanbur, R., eds. Poverty and policy in post-apartheid South Africa. Cape Town: HSRC. p. 59-94.)

HUNTINGTON, S.P. 1991. The third wave: democratization in the late twentieth century. Norman: University of Oklahoma Press.

JACOBSON, T.L \& SERVAES, J. 1999. Introduction. (In Jacobson, T.L. \& Servaes, J., eds. Theoretical approaches to particpatory communication. Creskill: Hampton. p. 1-13.)

JACOBSON, T.L \& STOREY, J.D. 2004. Development communication and participation: applying Habermas to a case study of population programs in Nepal. Communication theory, 14(2):99-121.

JACOBSON, T.L. 2003. On defining differentiating kinds of communication for Social Change: particpatory, non-participatory and their sub-types. Conference Papers, International Communication Association, Annual Meeting, San Diego.

KAJEE, A. 2006. Global corruption report 2006. Country Report: South Africa.

LAKATOS, I. 1970. Falsification and the methodology of scientific research programmes. (In Lakatos, I. \& Musgrave, A., eds. Critisism and the growth of knowledge. Cambridge: Cambridge University Press. p. 91-196.)

LERNER, D. 1964. The passing of the traditional society: modernizing the Middle East. New York: Free Press.

MAIL AND GUARDIAN. 2006. Municipalities chastised for late financial statements. http://www.mg.co.za/articlePage. aspx?articleid=283130\& area=/breaking_news/breaking_news_national/ Date of access: 25 Nov. 2006.

MAIL AND GUARDIAN. 2007. FXI: govt is gagging public health workers. http://www.mg.co.za/articlePage.aspx?articleid=316708\&area=/breaking_ news/breaki ng_news_national Date of access: 16 Aug. 2006.

MANTASHE, G. 2008. Focus on development. Focus, 52:24-25, Nov. 
MELKOTE, S.R. \& STEEVES, H.L. 2001. Communication for development in the Third World: theory and practice for empowerment. New Delhi: Thousand Oaks.

METH, C. 2006. Half-measures revisited: the ANC's unemployment and poverty reduction goals. (In Bhorat, H. \& Kanbur, R., eds. Poverty and policy in post-apartheid South Africa. Cape Town: HSRC. p. 366-458.)

MORROW, R.A. \& TORRES, C.A. 2002. Reading Freire and Habermas: critical pedagogy and transformative social changes. New York: Teachers College Press.

NAIR, K.S. \& WHITE, S.A. 1993. The development communication process: a reconceptualization. (In Nair, K.S. \& White, S.A., eds. Perspectives on development communication. London: Routledge. p. 47-70.)

NÄRMAN, A. 2006. Paulo Freire (1921-1997). (In Simon, D., ed. Fifty key thinkers on development. London: Routledge. p. 96-100.)

NEOCOSMOS, M. 2002. Democracy, rights discourse, national healing and state formation: theoretical reflections on the liberation transition in Southern Africa. http://nai.diva-portal.org/smash/ record.jsf?searchld=1\& pid=diva2:241795 Date of access: 28 Oct. 2008.

PADAYACHEE, V. 2006. Development discourse in post-apartheid South Africa. (In Padayachee, V., ed. The development decade? Economic and social change in South Africa, 1994-2004. Cape Town: HSRC. p. 1-13.)

PARSONS, R. 2001. Steps towards social dialogue and the development of NEDLAC in a democratic South Africa: 1979-2001. South African journal of economic history, 16:139-171, Sept.

RAMPHELE, M. 2008. Laying ghost to rest: dilemmas of the transformation in South Africa. Cape Town: Tafelberg.

RASMUSSEN, D.M. 1990. Reading Habermas. Cambridge: Blackwell.

ROBINSON, M., \& WHITE, G. 1998. Introduction. (In Robinson, M. \& White, G., eds. The democratic developmental state: political and institutional design. Oxford: Oxford University Press. p. 1-16.)

ROGERS, E.M. 1976. Communication and development: critical perspectives. Beverly Hills: Sage.

ROGERS, E.M. \& SHOEMAKER, F.F. 1971. Communication of innovations: a cross-cultural approach. 2nd ed. New York: The Free Press.

ROMAN, R. 2005. The place of theory in development communication: retrospect and prospects. (In Kalbfleisch, P.J., ed. Communication Yearbook 29. New Brunswick: Routledge. p. 311-331.)

ROMM, N. 1990a A critical evaluation of South African political theory. (In Alant, C., ed. Sociology and society: a humanist profile. Johannesburg: Southern Book. p. 34-40.)

ROMM, N. 1990b. Gouldner's reflexive methodological approach. (In Alant, C., ed. Sociology and society: a humanist profile. Johannesburg: Southern Book. p. 13-22.)

ROMM, N. 1990c. Berger's conception of development communication of society. (In Alant, C., ed. Sociology and society: a humanist profile. Johannesburg: Southern Book. p. 115-126.)

SCHRAMM, W.L. 1964. Mass media and national development: the role of information in the developing countries. Stanford: Stanford University Press.

SERVAES, J. 1995. Development communication: for whom and for what? Communicatio, 21(1):39-49. 
SOUTH AFRICA. 1994. RDP: white paper on reconstruction and development. http://www.treasury.gov.za/publications/other/gear/all.pdf Date of access: 14 Nov. 2008.

SOUTH AFRICA. 1996. Growth, employment and redistribution: a macroeconomic strategy. http://www.info.gov.za/view/DownloadFileAction?id =70427 Date of access: 14 Nov. 2008.

SOUTH AFRICA. 2006. Background document: a catalyst for accelerated and shared growth, South Africa (ASGISA). http://www.info.gov.za/speeches/ briefings/asgibackground.pdf Date of access: 14 Nov. 2008.

STOREY, J.D. 1999. Popular culture, discourse, and development: rethinking entertainment-education from a participatory perspective. (In Jacobson, T.L. \& Servaes, J., eds. Theoretical approaches to participatory communication. Cresskill: Hampton. p. 337-358.)

STRAUSS, D. 2006. The ontic interconnectedness and interdependence of language and communicative action. Communicatio, 32(1):101-118.

THE WORLD BANK. 2006. World development report 2007: development and the next generation. Washington: The World Bank.

VAN DER WALT, B.J. 2007. Ontwikkelingsamewerking vir Afrika, met besondere aandag aan 'n vennootskapsverhouding. Koers, 72(3):467-501.

VAVI, Z. 2008. Ten steps to a new economy. http://www.mg.co.za/article/200809-19-ten-steps-to-a-new-economy Date of access: 21 Sept. 2008.

WAISBORD, S. 2001. Family tree of theories, methodologies and strategies in development communication: convergences and differences. http:// comminit.com/pdf/familytree.pdf. Date of access: 10 Oct. 2008.

WHITE, S.A. 1994. Introduction - the concept of participation: transforming the participative society. (In White, S.A., Nair, K.S. \& Ascroft, J., eds. Participatory communication: working for change and development. New Delhi: Sage. p.13-32.)

WILKINS, K.G. 2002. International development communication: proposing a research agenda for a new era. (In Gudkynst, W.B. \& Mody, B., eds. Handbook of international and intercultural communication. 2nd ed. Thousand Oaks: Sage. p. 537-550.)

ZAAIMAN, J. 2007. Power: towards a third generation definition. Koers, 72(3):357-375.

ZUMA, J. 2009. Address by President Jacob Zuma in response to the debate on The Presidency Budget Vote, National Assembly. (Address addressed in parliamentary session on 24 June 2009). http://www.thepresidency. gov.za/show.asp?type=sp\&include=president/sp/2009/sp06251427.htm\&l D=1953 Date of access: 16 Feb. 2010.

\section{Key concepts:}

communicative action

developing democracy

dialogue

Freire

Habermas

postapartheid South Africa

public sphere 


\section{Kernbegrippe:}

dialoog

Freire

Habermas

kommunikatiewe aksie

ontwikkelende demokrasie

postapartheid Suid-Afrika

publieke sfeer 
